\title{
The Changing Conception of Industrial Policymaking in Korea.
}

\author{
CHOI, BYUNG-SUN \\ Assistant Professor, Graduate School of Public Administration, Seoul National University
}

\begin{abstract}
The conception of industrial policymaking in any country reflects its peculiar political, economic, and social context. As political and economic democratization proceeds in Korea, many important changes in industrial policymaking have recently taken place. But its fundamental change has been resulted from a coherent industrial policy reform undertaken during the early years of Chun's regime to correct policy failures and legacies left by the highly politicized heavy industrialization drive in the 1970s. It would be now fair to say that Korean industrial policy has come to bear a closer semblance to that of advanced industrialized countries. The concept of industrial targeting, which has long dominated the industrial policymaking in Korea, seems to have lost its traditional luster. On the other hand, political influence has begun to overshadow technocratic judgments in the making of industrial policy.
\end{abstract}

\section{Introduction}

Quite naturally, the conception of industrial policymaking reflects its political, economic, and social context. Up until the late 1970 s, the Korean state had not only selected industries to be fostered, but devised a complicated industrial policy framework in support of their growth. Industrial policy instruments were wideranged: from the promulgation of specific industrial promotion laws to the provision of low-interest rate loans and loan guarantees and to widespread import protection and indifference to monopolistic practices. Most industrial policy formulations took place within the economic bureaucracy, and political control over the policymaking process had been severely limited. Since around the late 1970 s, however, as the ill effects of such industrial policymaking practices became apparent, they have undergone a fundamental change. And with the transition to a democratized regime in the mid-1980s, important industrial policy discussions start to be made out in the open, political process. 
This article aims first at clarifying the process through which a "new" conception of industrial policymaking has emerged in Korea. And then, it will identify tensions and contradictions found characteristically in moving from one mode of industrial policymaking to another by way of analyzing some of the recent industrial policy episodes: 1) rationalization of non-performing and structurally depressed industries; 2) restructuring of Daewoo Shipbuilding Co.; and 3) the decision to privatize the Korea Heavy Industries $\mathrm{Co}(\mathrm{KHIC})$.

\section{Traditional Patterns of Industrial Policymaking}

\section{A. Economic and Industrial Policy in the 1960s}

Modern industrial policy in Korea has taken shape in the early 1960 s, when the Korean state launched the first five-year economic development plan. At the initial stage of industrial development, the emphasis was placed on the creation and the expansion of industrial infrastructure. Along with building social infrastructure, the government initiated some massive industrial investment programs such as oil refineries and steel mills in the 1960s in the form of public enterprises. The government also paved the way for the in-flow of much-needed foreign capital. The government promulgated "Foreign Loan Inducement Law" and accelerated the "normalization" talks with Japan, which was considered to be the major conduit of foreign capital.

In fact, by the late $1950 \mathrm{~s}$, foreign aid (particularly from the U.S.), which was linked to the reconstruction of the war-torn economy and constituted the single most important source of financing for the initial easy phase of import substituting industrialization in the $1950 \mathrm{~s}$, not only shrank rapidly, and but was soon to be terminated. This put Park Chung Hee regime, which took power through military coup in 1961, in a desperate situation within and out. From within it was forced to demonstrate its commitment to and its ability to achieve economic development. From outside, it ought to be able to attract and induce foreign capital, in lieu of foreign aid, for the economic development. This, in fact, was the underlying motive of the embarkation of economic development plan in Korea. The limited resources inevitably led the government to put more emphasis on creating social overhead capital.

The crux of industrial policy in the 1960s, however, can be found in a series of foreign economic policy reform designed to bring them in line with the liberal world trading environment. The unification and the realignment of the preexisting multiple exchange rates system(1952-60), the liberalization of import restrictions, and the intensification of export incentives (Frank et al. 1975) were some of examples indicating the Korean government's strategic turn to exportoriented development(Lim 1981). Under the new foreign economic policy regime, some low-skilled, labor-intensive industries including textile and clothing, 
plywood, footwear, and wigs soon emerged as growth export industries. Their emergence was not the result of the government's deliberate industrial targeting, but the new trade and exchange rate regime helped turn those previously unprofitable export industries into profitable ones.

\section{B. Industrial Policy and Policymaking in the 1970s}

At the dawn of the decade of 1970 s, however, the export-oriented industrial development, based largely on light industries, began to be challenged, at least , for two reasons. First, the liberal world trading environment, in which Korea and other NICs' exports had boomed, showed many signs of deterioration by the early 1970s (Fishlow et al. 1981; OECD 1979). Apart from the managed trade in textiles and clothing(Aggarwal 1983; Woolcock 1982), trade conflicts continued to expand rapidly into many labor-intensive industrial sectors such as footwear. Moreover, the increasing competition from many lesser developed, labroabundant countries such as China, Indonesia, and Thailand were rapidly shrinking Korea's edge in production and export of labor-intensive manufactured goods. As long as labor-intensive industries comprised the mainstay of Korea's exports in the early 1970 s, these adverse external developments represented a grave threat for. the future of Korea's export-led growth strategy and signalled an urgent need to diversify the composition of exports.

The second challenge was the heightened need for the development of defense industry, which was buttressed by the change in the U.S. military posture toward Korea and the increased tension with North Korea. The Nixon Administration announced its decision(called Nixon doctrine) to withdraw the U.S. ground forces from Korea in 1969. In March 1971, the Nixon Administration actually pulled out the U.S. Seventh Division in Korea, reducing American troops in Korea by one third. These sequence of events convinced Korean political and military leaders that they could not possibly delay the development of Korea's defense industry, which would require a strong heavy industrial base.

Korea's big push toward heavy and chemical industrialization (on its problematic definition, see Choi 1987: p. $90 \mathrm{n}$ ) in the early 1970s was a response to such challenges. Heavy industrialization was, however, almost entirely foreign to industrialists and government planners alike. Meeting this challenge provided an economic justification for President Park Chung Hee's instituting of more authoritarian and repressive Yushin(Revitalization Reform) regime in 1972(Ibid.: pp. 97-99). With the turn to heavy industrialization, the so-far market-oriented Korean economy had begun to be highly politicized. The style of economic and industrial policymaking was greatly changed and the state intervention in the private sector's investment decisions went deeper and became more specific, as the state sought to channel a far greater proportion of resources toward statedesignated heavy industrial sectors. 


\section{1) Industrial Targeting and Export. Orientation}

The accelerated development of heavy and chemical industries in the 1970s hinged on two strategic elements(MCI 1973). One was industrial targeting (Krugman 1983: pp. 9-11). The Ministry of Commerce and Industry(MCI) selected six "strategic industries:" iron and steel, machinery, nonferrous metals, electronics, shipbuilding, and petrochemicals. The promotion of basic industries such as steel and petrochemicals was indisputable for reasons of developing defense industry and securing a more stable supply of these key materials. Particularly, defense industry-related concerns prevailed in selecting nonferrous metals smelting industries(aluminum, copper, zinc, and lead), which are highly import-dependent and energy-intensive. The selection of the electronic and shipbuliding industries was motivated by the second strategic consideration: export-oriented development of heavy industries(KDB 1981: pp. 11-13). These industries were expected to stimulate development of a variety of other supplying industries(or bottleneck industries) through backward linkage effects(Hirschman 1971: pp. 104-105). Given Korea's advantage of cheap labor cost, these industries were thought to have better prospects for growth as leading export industries in the near future. Development of the machinery industry was targeted to meet rapidly growing capital goods demands at home.

The MCI's plan envisaged a sharp expansion of production capacity of these industries during 1973-81: from six-fold (petrochemicals) to thirty three times(shipbuilding), far outpacing the projected level necessary to meet growing domestic demand. The share of exports in total demand for major industrial goods was planned to reach somewhere between 25.1 percent(power tillers) and 78.5 percent (shipbuilding) in 1981 from a negligible level in 1972. The MCI's plans for a sharp expansion of production capacities and export-oriented development of heavy and chemical industries went hand in hand with each other. The small domestic market no longer figured prominently in the new plan. In so far as exports overcome domestic market constraints, the central policy concern shifted to attaining international competitiveness by securing economies of scale.

2) Politicization of Industrial Policymaking

To spearhead the heavy industrialization drive, President Park created in May 1973 the Heavy and Chemical Industry Furtherance Committee(HCIFC), consisted of several economic ministers. In September, the HCIFC established a Planning Council, a standing staff organization. The real intent of establishing the Planning Council was to strengthen President Park's direct control over the economic decision-making for heavy and chemical industries. The Planning Council was chaired by the Second Economic Secretary(and prior to February 1974, by the First Economic Secretary) to the President. Based on the President's strong mandate and direct involvement, the Planning Council became the center of 
economic decision-making concerning heavy industrialization policies. New development plans and investment projects were initiated jointly by private firms, concerned ministries(in most cases, the Ministry of Commerce and Industry) and the Planning Council. Economic decision-making was short-circuited through the Planning Council and the Second Economic Secretary and directly to the President, frequently by passing the Economic Planning Board(EPB). The EPB had little control over privte businessmen's access to the Second Economic Secretary or their direct access to the President.

Major economic decisions concerning heavy industries were dictated increasingly by the developmental-nationalist passion of the people who were strongly committed to the President's cause: the acceleration of heavy industrialization at any cost. The EPB planners were convinced that such economic decision-making caused excessive and redundant investments by rival chaebol (big business conglomerates) groups in some heavy industrial sectors such as power generation and heavy construction equipment. Indeed, the excessive investments in these industrial sectors put enormous strain on the economy from the late 1970s to the early 1980s.

Despite high market risks and uncertainties involved in making investments in the technologically unfamilar lines of business, major chaebol groups rushed into these now privileged sectors. They believed their future lay in these sectors. They also believed that once they commit some of their resources, the government would support them(Park 1984). President Park's extraordinary commitment to heavy industries and his apparent control of the actual microeconomic policy actions governing cash flows made investments in this sector subject to relatively low levels of strategic uncertainties(Barzelay 1986: pp. 46-50). Under these circumstances, private investors reasonably believed that as long as they embodied the political leadership's vision of the desired politico-economic order, they could influence the state agencies's decision-making and secure resources and support necessary to make their otherwise highly risky business undertakings economically valued(lbid.: p. 81). They also believed that the sheer size of heavy industrial investments would preclude the possibility of the government's roll-back of its promotional efforts.

To secure economies of scale, the EPB and the MCI at first restricted entry to the heavy and chemical industrial sectors by selecting one or two eligible chaebol groups which had interest in participating in these industries and had demonstrated the capability to undertake such ventures. But the MCl's strategy did not last long, as the rival chaebol groups came up with different estimates of export demand and claimed their right to participate in those industrial sectors. The strategy to develop heavy industries as leading export industries in the future stimulated an excessive optimism about export potential. At the same time, domestic market demand tended to be overestimated(Hirschman 1971: p. 99n). 
The EPB planners and the MCI policymakers, uncertain about export demand in the future, tended to err on the side of overestimating export demand. They were also ambivalent about two contradicting policy goals: achieving economies of scale on one hand, and promoting competition and diversification of technology sources, on the other.

\section{3) Industrial Policy Instruments}

The most crucial problem of heavy industrialization was obviously the shortage of long-term capital needed both to finance huge heavy industrial investments and to support thcir operation for a considerable period of time until they could stand on their own and bear profits. To finance the huge amount of capital investments, the Korean government further tightened its control over the financial system. The easiest and surest way to channel funds to specific sectors has been to establish specialized state-run banks or earmark part of funds of the commercial banks as "policy funds." The result was the proliferation of policy funds in the 1970s and the increased segmentation of financial market and financial resources, limiting the discretion of asset management of the financial institutions.

The undisciplined expansion of preferential policy loans resulted in a sharp increase of their share of total bank credit from less than 40 percent in 1971 to 68.7 percent in 1978 (Nam 1984: p. 8). Thanks to preferential policy loans, more than 77percent of total manufacturing investment during 1976-78 was undertaken in the heavy and chemical industries which accounted for only about 50 percent of total manufacturing output(Ibid.: p. 10). In addition to domestic credit, the EPB channeled $\$ 3.8$ billion from 1973 to 1978,32 percent of total foreign loans toward heavy and chemical industries(BOK 1983). From 1977 onward the trend accelerated, with the result that these industries accounted for more than 80 percent of the total foreign loans(and all public foreign loans) in the manufacturing sector, leaving less than 20 percent for light industries(Ibid). At the same time, public foreign loans increased rapidly to finance infrastructure investments. The inducement of forcign borrowing further constrained the allocation of domestic credit by the banking institutions. As an ultimate guarantor of foreign loans, the government has been obliged to supplying domestic credit as well as working capital for the successful operation of the foreign loan-financed projects.

Heavy and chemical industries also received special tax preferences. "Tax Excmption and Reduction Regulation Law" at first provided tax preferences only for a limited number of so called "important industries" such as iron and steel, machinery, and eletronics. Over the 1970s, however, other industries such as autos, various metal products, and electrical appliances were also designated as important industries. In 1978, the heavy and chemical industries' ratio of corporate income tax exemptions and reductions in the tax bill amounted to 40.1 percent, while that for light industries was only 8.0 percent(Young 1984: p. 49). 
Moreover, the so-called important industries received tariff privileges in importing investment goods.

Import protection also played a crucial role in securing the profitable operation of these heavy industries. Over the 1970 s, the $\mathrm{MCl}$ not only erected non-tariff barriers for newly-established heavy industries, but also for the industries using domestically-produced intermediate inputs. As a result, import liberalization(as measured by the ratio of freely importable items/total number of items) in the 1970s remained below the level achieved in 1968. The ratio of import liberalization in early 1978 was 53.9 percent, recovering slightly from the trough of $\mathbf{4 9 . 5}$ percent in 1975, but falling far short of 61.7 percent of 1968(Ibid.). Particularly in the latter half of the 1970), the MCI erected various indirect import barriers on machinery imports that could possibly be substituted by domestic suppliers. It also set an annual domestic content ratio to limit imports and to promote local production of machinery and equipment.

In addition to quantitative import restrctions, the Ministry of Finance maintained an elaborate and extensive tariff rate schedule. One preliminary study of Korea's tariff structure shows that it was overly skewed and that it provided far greater protection for the heavy and chemical industries. The average effective rate of protection for these industries was 71 percent, far higher than that for light industries(-2 percent; lbid.: p. 46). Another study shows that the inter-industrial tariff structrue grew more complicated over the 1970s such that both nominal and effective rates of protection were greater for highly processsed intermediate goods, machinery, and transportation equipment, although their absolute level declined over time (Kim and Hong 1982).

Finally, other ministries were also involved in the heavy industrialization drive. The Ministry of Construction (through the Industrial Estate Development Corporation under it) built several large scale industrial estates for each major industry: $C h$ ' angwon Industrial Estate for machinery; Ulsan and Yoch'on for petrochemicals: Kumi for electronics; and Onsan for non-ferrous metal smelting industries. The $\mathrm{MCI}$ established many individual industry-specific research and development $(\mathrm{R} \& \mathrm{D})$ institutes. The Ministry of Education greatly increased the number of technical training schools and colleges to meet the rapidly growing demand for skilled labor.

\section{4) Legacies of Heavy Industrialization Drive}

The accelerated growth of heavy and chemical industries transformed Korea's industrial structure, substituted substantial amount of intermediate and capital goods imports and significantly upgraded the composition of Korea's exports. Heavy and chemical industries' output grew at an average annual rate of 21.4 percent between 1970 and 1979, compared to light industries' growth of 14.8 percent. Their share of value-added in total manufacturing increased from $\mathbf{4 1 . 8}$ 
percent in 1970 to 54.7 percent in 1979 , while its share of total manufactured exports grew from 16.5 percent to 42.5 percent during the same period(EPB 1980).

The accelerated growth of the heavy industries exacted a high price, however. The need to mobilize massive financial resources and to channel them selectively toward the heavy industrial sector added far more rigidities to the financial system and further segmented the financial market. Foreign debt swelled from $\$ 2,250$ million (28.6 percent of the GNP) in 1970 to $\$ 8,460$ million(41.8 percent of the GNP) in 1975 and to $\$ 27,370$ million(48.5 percent of the GNP) in 1980(EPB 1984: p. 56), Moreover, unbalanced allocation of resources retarded modernization of other industrial sectors. The heavy protecion of the "infant" industries not only reversed the trade liberalization policy of the mid 1960s, but it contributed greatly to a more monopolistic and oligopolistic market structure and to an even higher concentration of economic power in a small number of chaebol groups(Jones 1980). But nothing was more serious than a rising inflation problem, at least in the short run.

\section{Import Liberalization Policy: Counterweight to the Heavy Indus- trialization Drive in the Late 1970s}

The Korean economy's unprecedented high economic growth in the late 1970 s was propelled by massive investments in the heavy and chemical industries. But economic policy mismanagement also produced high inflation, which in turn was created by an extraordinarily rapid increase in the money supply mainly from the foreign sector. In addition to strong exports, the increasing receipts of foreign exchange from the Middle East construction services, which were not fully anticipated, accelerated the growth of money supply. Domestically, agricultural subsidy programs produced high fiscal deficits. The heavy industries and agricultural subsidy programs, however, were highly politicized and privileged sector of President Park's Yushin regime. The foreign exchange earnings from the Middle East construction could not simply be discouraged for their inflationary effects. These political considerations severely constrained the EPB planners' policy efforts to combat inflation.

Under these conditions, the EPB planners saw import liberalization as a strategic policy instrument. First of all, expanding imports would certainly help relieve supply shortages and stop foreign exchange holdings from exerting inflationary pressures. More important, import liberalization would enable the EPB planners to reduce inflationary pressures without making a drastic change in the existing macroeconomic policy framework (geared to promote high economic growth and accelerated investments in the heavy industrial sector), or restricting the inflow of technology-embodied foreign loans. Second, more fundamental element of their strategy, they believed that the adoption of import liberalization 
policy would help discourage excessive and redundant heavy industrial investments. Moreover, import liberalization would open a window of opportunity for the EPB to further introduce more market-oriented economic policies, turning clandestinely around from the selective and discretionary state intervention in the process of rapid industrialization(Choi 1987: pp. 213-16).

The EPB's emphasis on price stability in pursuing import liberalization backfired, however. Because price stability was considered an economic policy goal for which the EPB was primarily responsible, other economic ministries resisted the EPB's prerogative. For example, the $\mathrm{MCl}$ refused to liberalize items the EPB requested for long-term industrial policy reasons. The Ministry of Agriculture and Fisherics rcfused to expand imports of agricultural products for political reasons. The Ministry of Health and Social Programs resisted the EPB's pressure to liberalize imports of cosmetic and pharmaceutical products for their negative social impact.

For these reasons, the EPB's import liberalization policy failed to go far enough to curb inflation. Neither was it successful in discouraging unwarranted heavy industrial investment projects. At last, continued inflation cost the Yushin regime dearly. Tapping the coalition of the disaffected-students, labor, intellectuals, and progressive church leaders, the opposition intensified their attack against the repressive Yushin regime accusing its economic policy mismanagement. The elections for the National Assembly in December 1978 saw the oppostion New Democratic Party win more popular votes than the ruling Democratic Republic Party, although it did not win a majority in the Assembly. The defeat of the DRP in the national election was attributed, in large measure, to high inflation. It was only after the election that President Park really came to grips with the seriousness of the inflation problem. President Park reshuffled the cabinet right after the election, and gave the new Deputy Prime Minister(DPM) Shin Hyon Whack a clear mandate to institute a comprehensive policy meaures to combat inflation.

In April 1979, after the extraordinary Blue House economic policy meeting(Ibid.: pp. 253-56), the newly appointed DPM Shin Hyon Whack announced the "Comprehensive Measures for Economic Stabilization." They included deregulationg prices and accelerating import liberalization, suspending major investment projects and restructuring excessive heavy industrial investments, adopting restrictive monetary policy and reducing policy loans, and controlling real estate speculation. The EPB's reform-minded economic policymakers took the opportunity to institute a set of cconomic policies which were more market-driven and structural. But the time was then against President Park. In the midst of increasing political and social tension, he was assassinated in October 1979, and the Yushin regime, which had been so closely identified with him, collapsed. But major economic policy reform ideas embedded in the "1979 Measures" survived the difficult times following the economic recession and the political turmoil in 
1980 came to constitute the backbone of the eocnomic policy reform in the $1980 \mathrm{~s}$.

\section{Building A New Institutional Framework for Industrial Policy- making in the Early 1980s}

With the transition in government in 1980, the EPB's market-oriented economic policy reform gained a renewed impetus. The macropolitical changes brought with the rise of the military to power were calling for a departure from the traditional economic and industrial policymaking practices. The top decisionmaker's tendency to rely more heavily on the EPB in the transitional period, in view of its superior analytic and managerial capacity in dealing with the social and economic crisis at the time, strengthened the EPB's economic policy leadership.

During the early years of the Chun government, the central economic policy issue was stabilization. Although the world economic recession much relieved inflationary pressure at home, the government's consistent mix of stabilization policies such as maintaining a stable effective exchange rate, prudent demand management, moderation of wage increase(through the government's informal guidelines and moral persuasion) and food prices contributed as much to economic stability from late 1981 (Haggard and Moon 1986; and Aghevli et al. 1985). From around that time, the EPB began to undertake the delayed task of structural adjustment on the basis of economic stability and with an aim to further consolidate it (Roberts 1985).

\section{1) Rearranging Industrial Assistance System}

The EPB's concern for structural adjustment originated from its experience in the period of difficult economic adjustment during 1979-80. While many heavy industries were saddled with excess capacities or frozen in the middle of construction, the Korean economic policymakers counted heavily on traditional laborintensive light industries, such as textiles and clothing and footwear, in shoring up export and employment. However, these industries, which had suffered over the 1970s from a biased allocation of resources against them, failed to meet such expectation. The EPB argued that the under-investment into these industrial sectors caused price increase in wage goods(that these sectors produce) and wage increases, in turn, eroded export profitability. Their analyses led them to the conclusion that to secure efficient allocation of resources among competitive industries, the existing discriminatory industrial assistance system should be revamped and that, among others, numerous industry-specific laws, which had over the 1970s proliferated under this system, should be replaced by an omnibus industrial assistance law to be applied uniformly across industries.

In fact, the EPB had since 1976 made sporadic attempts at such a legislation(EPB 1982: pp. 178-79). In 1978, for example, in the midst of increasingly unruly inflation, the EPB had again accentuated such legislation attempt as a part 
of long-term anti-inflation policy package. But President Park's unflinching commitment to the heavy industries and his tendency to secure a full range of government's support for each major heavy industry through industry-specifcic laws had frustrated the EPB's attmepts. Also, the Ministry of Finance and the $\mathrm{MCl}$, which had jurisdiction over those industry-specific laws, strongly resisted. The MCI and the MOF were suspicious of the EPB's attempt: they understood it as the EPB's covert scheme to eviscerate their legitimate authority over industrial policy instruments. In such a conflictual situation, the proposed legislation was shelved by the EPB itself. The EPB's legislation efforts to overhaul industrial assistance system was consummated as the President Park's regime collapsed and many EPB's reform-minded planners came to help the new government mold a new set of economic and industrial policy. In September 1980, when president Chun was sworn in, the EPB pushed its legislative plan forcibly ahead. As expected, the EPB's initiative was again challenged strongly by the MOF and the $\mathrm{MCl}$. And the jurisdictional battle was fought on until November, when Prime Minister Nam Duck Woo(former DPM from 1974 to 1978) stepped in and upheld the EPB's claim. The preparation had since proceeded speedily. The EPB completed its first draft of "Industrial Assistance Law" in September, acquired the president's prior approval, made some revisions to it and finally presented it for interministerial and public review in December.

According to the proposed "Industrial Assistance Law,"(KDI 1981: pp. 12671283) no industrial assistance would be provided on industry basis(for example, "strategic industries" or "major industries"), but only on the basis of its functional merits; on the other hand, investment into highly protected industrial sectors would be discriminated. Second, the type of assistance would be restricted to tax incentives(either accelerated depreciation or investment tax credit); tariff exemption or reduction would be abolished. Third, various kinds of preferential policy loans would be consolidated to support "promising" infant heavy industries. Fourth, "promising" industry would be protected for only a prespecified period of time(3-6 years). Fifth, for effective coordination of industrial policies, the DPM would be given an ultimate authority to allocate industrial assistance through deliberation by the Industrial Policy Deliberation Council(IPDC) to be chaired by the DPM himself, and the DPM could request change in policies initiated by the MOF(in regard to tax and financial assistance, tariff rate adjustment, etc.) and the $\mathrm{MCI}$ (in regard to import liberalization, for example) when they are found not in accordance with its overall industrial policy objectives. In short, the EPB intended to reduce government intervention in the economy by strengthening its grip on industrial policy instruments. 
2) The Establishment and the Operation of the Industrial Policy Deliberation Council(IPDC)

In the face of strong resistance from the MOF and the $\mathrm{MCI}$, the EPB revised the draft several times. But it still stopped short of alleviating their suspicion and concern. MOF's Minister Lee Sung Yoon and MCI's Minister Suh Suk Joon attacked the proposed law as "strengthening government control rather than promoting private sector autonomy." The Presidential Secretaries, other than the Economic Secretary, advised the President that the legislation was "provocative and politically risky," allegedly reflecting business' concerns and misgivings about the EPB's real intention. For business which had benefitted from the existing industrial assistance system, it was nothing but an unwanted confusion and all kinds of uncertainty about what they would get under the new situation. In the midst of prolonged dispute among concerned ministries over the legislation, Presidential Economic Secretary Kim Jae-Ik and EPB's Assistant-Minister Kang Kyong Shik(in whom DPM Shin Byong Hyon placed full confidence regarding the matter) took the opposition by surprise and secured "Presidential special directives concerning operation of industrial assistance system" in August 1981. The most important change resulted was the establishment of the IPDC under the DPM at the end of that year. Even though the IPDC was supposed to take the form of public industrial policy forum that includes some experts chosen from outside the government and appointed by its chairman as its members as well, it has been composed exclusively of economic ministers and the DPM as its chairman. The presidential decree also provided for public hearings and advisory committees that would be composed of those people appointed by the DPM for their knowledge and expertise on economic and industrial policy matters. However, these provisions remained idle until March 1985, when the government felt the need to allow private sector more voice in industrial policymaking. At any rate, based on the new decree, private sector consultation committees have since proliferated.

Policy issues that ought to be brought to the IPDC's table are wide-ranged: (1) tax exemptions and reductions or their withdrawal; (2) tariff rate readjustment, tariff exemptions and reductions, and tariff installment payment scheme; (3) export and import restrictions or removal of them; (4) operation of major policy funds and the Korea Development Bank funds; (5) major public and private investment projects that require large-scale government assistance; (6) and other issues meriting the IPDC's attention. From December 1981 to the end of 1985 , the IPDC have been held 42 times and it handled 79 agenda items. An analysis of the IPDC agenda for the period(Choi 1987: pp. 74-78) shows that the EPB's major policy concern has been with altering interindustry allocation of tax and financial incentives and removal and reduction of import protection. 


\section{3) Controversies over Import Liberalization}

Although the EPB's proposed legislation of the omnibus "Industrial Assistance Law" was aborted, the EPB did not abandon its efforts to revamp the existing economic and industrial policy framework. It began to exert its influence as its industrial policy leadership secured and consolidated by the establishment of the IPDC. Its first task was to design a new set of industrial policy guidelines for the IPDC deliberations and set the timetable for economic liberalization. The Korean Development Institute(KDI), the EPB's think-tank, was mobilized to make expert analysis and devise schemes for redesigning industrial assistance system. As the KDI's initial report was not found satisfatory, the IPDC decied to call another in: Korea Institute of Industrial Economics and Technology (KIET), which had just been put under the jurisdiction of the $\mathrm{MCI}$. Controversy over economic liberalization and import liberalization in particular had since been heightened between the two governmental institutes and the economic ministries in support of each side.

Among others, the KDI's provoking study entitled "Basic Issues of Industrial Policy and a Scheme for Redesigning Industrial Assistance Measures(Young 1982)" triggered the controversy over industrial assistance system and touched off the so-called KDI-KIET dispute over import liberalization in the spring of 1983. Stressing the need to accelerate import liberalization in view of the slackening competitiveness of export industries, the report advocated a radical import liberalization policy(KDI 1983). The study advised the government to: (1) replace all quantitative import barriers with tariff protection during 1984, with an exception of food grains; (2) reduce differential effective rates of protection among industries gradually; (3) curtail all nominal tariff rates linearly each year over the course of four years (1985-88) to bring them below 30 percent at the highest; and (4) strictly restrict special tariff protection and other types of industrial assistance only to industries and items that could possibly attain competitiveness and have technological spin-offs for other related industries and only for a prespecified length of time. The KIET countered the KDI's radical proposal with a conservative, gradual approach to import liberalization(KIET 1982).

The first point of contention centered around "promising infant industry(Schultze 1983). What are "promising" or "winning" industries in the future? Who will pick them? What must the government do for them? The KIET believed in government's role to pick and foster important and promising industries by providing protection. The KDI dissented. The KDI maintained that only the market forces could determine the future "winners," and that the best way to develop competitive export industries was to let them compete in the world market, "as vindicated by successful cases of textiles and plywood industries in the 1960s, shipbuilding and electronics in the 1970s, and color television sets in the early 1980s." The KDI asserted, "Most of the industries that the government selected 
in the 1970 s as "important industries," are now at comparative disadvantage. Structurally depressed industries, higher concentration of economic power, presence of unqualified businessmen, and impairment of market mechanism all resulted from nationalist patriotic passions in the 1970s. The government's picking up winner industries can at best be a gambling." The KIET contended, "Continued government assistance and protection, at least for a specified period of time, is necessary to induce further private investment into strategic industries(basic raw material industries, and industries characterized by high income elasticity and strong linkage effects) and leading export industrial sectors."

The second point of argument was related to trade strategy. The KIET's position was that "when protectionist sentiments are pervasive in all industrial economies, one-sided and hasty import liberalization would be detrimental to national interest." The KDI retorted, "Improt liberalization is a task that we have to carry out for the good of our own economy and export industries, in particular. If we continue to follow import-substitution policy just because advanced nations tend to strengthen protectionism, we have to accept inevitable consequences such as higher inflation, reduced growth, and higher unemployment. Moreover, not all the advanced countries are intensifying protectionist trend; some of smaller economies such as Benelux are highly concerned about such trend. Nor is the rising protectionism in the industrial countries a rational choice but it is a result of political trade policy-making process in those economies. Accordingly, the possibility of using import liberalization as a bargaining chip in trade negotiations is slim. After all, it is small countries with poor resource endowment which stand to benefit more from free trade."

The final point of contention was concerned with the balance of payments effects of import liberalization. The KIET argued, "A stable balance of payments surplus situation was a precondition for successful import liberalization in the case of West Germany and Japan. Simultaneous elimination of quantitative import control and tariff rate reduction would cause imports to surge and inflict a damage to domestic industries." The KDI contended, "Imposition of differential tariff would prevent import surge; Moreover, in the long run, the gradual reduction of tariff rates would not only help increase export through facilitating efficient allocation of resources toward competitive exporting industries, but it would help increase domestic savings through price stability; and net result would likely be an improvement in the balance of payments."

The KDI-KIET controversy was relayed to an interministerial dispute: the EPB and the MOF on the KDI's side and the MCI on the KIET's. Interestingly enough, the Ministry of Finance(MOF) took side devotedly with the KDI. The MOF's conversion to economic liberalism owed to the personnel change, a few months earlier, in upper echelons of the Ministry. Business circle reacted generally in support of the MCI's gradual approach. The Federation of Korean Indus- 
tries(FKI) contended that "neither the preconditions for import liberalization-a stable external balance, world economic recovery and reduction in protectionism, improvement of business environment, nor supplementary policy measures arc ripe for accelerating import liberalization(FKI 1984)." The FKI emphasized that the government ought to give adequate time for business to develop technology and improve weak corporate financial structure. The Korea Chamber of Commerce and Industry(KCCI) and the Korean Traders Association(KTA) were not as vocal as the FKI, but they also emphasized the importance of gradual and incremental approach to import liberalization in view of general unpreparedness of industry.

4) Setting Industrial Policy Guidelines and Timetable for Economic Liberalization

Based mostly on the KDI's report, the EPB prepared a proposal entitled "Industrial Policy Issues in the 1980s and the Direction for Rearranging Industrial Assistance Measures(EPB 1983)," and presented it as an interim report to the President. Its crucial components were:

(1) accelerating import liberalization (tariff reduction and import liberalization through advance notice plan);

(2) promoting domestic market competition(strong enforcement of the Fair Trade Law of 1981, financial sector liberalization);

(3) accentuating technology and manpower development; and

(4) promoting industrial adjustment(scrapping of structurally depressed, declining industries, and fostering "promising" export industries, technology-leading and resource-saving industries).

When the proposal was submitted to the IPDC and the Ruling PartyGovernment Consultation Meeting in May 1983, it was met with criticism. Most controversial issues were about: (1) declining and structural recession industries (plywood, low-quality textile products, energy-intensive industries were selected as examples); (2) the target import liberalization ratio for 1983-84; and (3) agricultural sector import liberalization. Leaving these thorny issues unsettled, the IPDC authorized the EPB's proposal, which set the time schedule for major policy reforms to be undertaken within the year: the MOF was to complete the tariff reform by the end of September; and the $\mathrm{MCl}$ was to complete the advance notice import liberalization plan by October 1983(Ibid.). Although the KoreaU.S. trade negotiations touched-off after Reagan's visit to Korea in November 1983 and the USTR investigations since 1986 gave added impetus to the plan, the basic policy guidelines concerning import liberalization remained almost intact. 


\section{Promulgation of "Industry Development Law" and the Revision of "Tax Exemption and Reduction Law"}

As such, while the new directions of industrial policy for the 1980s and beyond were firmly in place, the three economic ministries(EPB, MOF, and. MCI) continucd to fight an intense jurisdictional battle. The EPB proposed in late 1983 a new law on which it could pursue rationalization of structurally depressed industries and declining industries. Its initiative was once again frustrated, however, in the face of the MOF's and MCI's resistance. In the meantime, financial problems of such industries as ocean shipping, foreign construction, and footwear grew severcr, and the accentuated economic concentration in the hands of chaebol groups became a politically volatile issue. Under these circumstances, the EPB sought again the possibility of legislating a special law which would regulate economic concentration. Believing that the policy instruments required for such policy purpose were all in its own hand, the MOF preempted the EPB's initiative. And it bcgan to initiate in the fall of 1984 an "Industrial Rationalization Law," which would deal with all the industrial policy issues at the time; namely, amelioration of economic concentration, and rationalization of structurally depressed and declining industries.

In the midst of such an interministerial jurisdictional battle, the MOF and the MCI dccidcd to go their way and began to accelerate each own's legislation move. On one side, the MOF focussed its effort on revising the "Tax Exemption and Reduction Law" with a view to facilitating industrial rationalization, which would be undertaken volitionally or on government compulsion. The revised Law of 1985 thus contained new special provisions for corporate income tax and transfer tax privileges which would be applied to firms designated as "industrial rationalization firms" when they merge and/or restructure lines of businesses. It also provided for tax reliefs for the banking system which would otherwise suffer from non-performing debts.

On the other side, between August 1983 and October 1985, the MCI sped its lcgislation of "Industry Development Law," which would replace seven major industry-specific laws. As such, the main thrust of the law was basically the same as envisaged in the "Industrial Policy Issues in the 1980 s and the Direction for Rearranging Industrial Assistance Measures" of 1983. One additional impetus toward such a legislation came from the recognition that the existence of industry-specific laws was now more likely to invite retaliatory actions(for example, countervailing duties) by foreign governments(the U.S., in particular) on account of implicit production and export subsidies provided for in them.

The meaning of legislating such law was that, over the process of intense policy competition among concerned ministries, the new industrial policy direc- 
tions originally advocated by the EPB was reconfirmed and put into legal code, and that the $\mathrm{MCI}$ itself, which was initially opposed to such legislation, came to understand the inevitability of departing from the previous industrial policy practices. What was fortunate for the $\mathrm{MCI}$ was that the legislation could be finalized by its own hand and thus save its face as the legitimate authority over industrial policy despite intense struggle among various industrial bureaus within the Ministry and the incessant challenge from outside for the authorship of the Law.

\section{E. Financial Sector Liberalization}

The state control over the financial system, the most powerful industrial policy instrument in Korea(Johnson 1985: pp. 307-309; Mason et al. 1980: pp. 336-337), has undergone a remarkable change in the 1980 s, also. And the change mirrored the same reflections on the misplaced inducement mechanisms used in the heavy industrialization drive in the late 1970s. By 1979, when the second oil price increases shook the economy and the consequent economic recession began to set in, the vicious circle of the state control over financial system was evident. Highly-leveraged big businesses could not withstand economic recession. This necessitated the provision of huge amount of relief loans. And the end result was the accumulation of non-performing debts in the banking system, undermining the consistency of economic stabilization policies at the time. Against this background, two drastic policy measures were undertaken by the Chun government in 1980: first, the heavy industrial restructuring attempts(Choi 1987: Ch. 3); second, measures to make corporate financial structure healthy by obligating big businesses and chaebol groups to sell their business-unrelated land holdings and divest of minor lincs of businesses(Ibid.: Ch. 5). But both turned out to be a vast failure, only to give policymakers a dear lesson that to break out of this vicious circle the financial system itself should be liberalized first.

Based on the "Measures for Deregulating the Commercial Banks." (KDI 1981: pp. 699-718), approved by President Chun in November 1980, the MOF divested government-owned equity share of the Hanil Bank in June 1981. Also, the MOF began to remove various government regulations on the internal management of the commercial banks, while it instituted new set of regulations to prevent any individual or business group from exercising managerial control of the privatized bank. The MOF took further steps to make financial institutions more competitive and autonomous. For example, it established a commercial paper(CP) market to be operated by finance and investment companies; lowered the required reserve ratio from the average rate of 23 percent in 1979 to 3-5 percent level in 1981; and replaced direct credit controls(credit ceilings and quotas by individual banks) by indirect way of controlling the money supply through changing reserve requirement in January 1982.

However, the financial sector reform has since become increasingly sluggish 
due mainly to the Chun's regime's ambivalent posture toward and its inconsistent approach to it. It conceived the financial sector liberalization as its major policy objective, but the economic circumstances necessitated retaining of government control over the financial institutions. For one thing, the government had to deal with industrial adjustment of financially distressed big businesses which suffered not only from the underutilization of huge heavy industrial investment projects, but from the continued tight monetary policy designed to achieve price stablity. For the other, it had to divert greater portion of financial resources to other industrial sectors to help recover from deep economic recession. In addition, the Ministry of Finance had been extremely recalcitrant to financial sector reform. In its view, as long as there existed an absolute need for continued intervention in the financial system, there was no point in deregulating the financial system.

Unexpectedly, the curb market incident, which broke out in May 1982 in the midst of such deadlock, gave immense impetus for the government to move forward. The incident was not only the largest one in Korea's history(about $\$ 300$ million), but politically scandalous, as a woman involved in the incident, Chang Yong Ja, was distantly related by marriage to President Chun. In these circumstances, President Chun replaced the Prime Minister and elevated Vice-Minister Kang Kyong Shik, a leading "EPB squad" in the MOF to change the conservative mood there, to the Finance Minister. As expected, he immediately announced two drastic policy measures: On June 28 , a sharp reduction in interest rate by an average of 4 percentage points and the elimination of preferential interest rates for priority sectors including export financing; and on July 3, the proposed promulgation of a special law to adopt a "real name" system from 1984, whose aim was to crackdown the curb market by banning anonymous financial transactions(The then aborted real name system will be instituted in 1991).

The MOF sped the denationalization of three other commercial banks: Korea First Bank and the Bank of Seoul and Trust Company in 1982, and the Chohung Bank in 1983. Thus with the Commercial Bank of Korea already in private hands since 1972, the denationaliztion of all the five leading commercial banks was completed(BOK 1985: pp. 5-6). To promote competition in the banking industry and to strengthen a link with international financial markets, the MOF lowered entry barrier significantly. Two joint-venture commercial banks with Korean and foreign partners were established: the Shinhan Bank, capitalized by Korean businessmen residing in Japan, in July 1982; and the KorAm Bank, subscribed to by the Bank of America and major companies in Korea, in March 1983. In July 1982, the government also lowered entry barriers for non-bank financial institutions such as the investment and finance companies and the mutual savings and finance companies. As a result, the number of such non-bank financial institutions increased conspicuously(Park 1985: p. 95). Moreover, their share of domestic 
deposits increased rapidly(Cho and Cole 1985).

The deregulation measures illustrated thus far may suggest that there had been a substantial progress. In words of Park Yung Chul(economics professor of Korean University and formerly the Economic Secretary to President Chun), "these reform measures were significant and refreshing developments in a country long suffered from financial repression. Most of all, they reflected the government's determination to develop a freer financial system where the price mechanism reigns and to open the financial industry to foreign competition. It should be pointed out that the various reform measures did not alter the modus operandi of financial control to any significant degree. Rather they indicated the direction the financial reform was going to take."(Park 1985: p. 97). Typically, even after denationalizing the commercial banks, the government still influences the appointment of the presidents of the banks through "consultation." Moreover, the Minister of Finance still presides over the Monetary Board, established in the Bank of Korea as the supreme monetary and credit policy authority, degrading the Monetary Board as a rubber stamp, although several versions of proposed amendment to the Bank of Korea Law to secure independence and autonomy for the central bank and the Monetary Board are currently debated among the MOF, Bank of Korea itself, and political parties.

\section{Recent Industrial Policy Episodes}

In addition to the industrial policy reform explained thus far, the recent major democratic Constitutional and political changes press for further changes in the conception of industrial policymaking(Choi 1988). Under the new Constitution of 1987, the principle of check and balance has been firmly established. And as the three opposition parties, taken together, constitute the majority of the thirteenth National Assembly, the oversight function by the National Assembly has been made unprecedentedly secure and strong. Moreover, the political parties, press, labor unions, and various interest groups claim increased political voice in industrial policy matters, which had been regarded largely as technocratic issue.

Three recent industrial policy episodes to be analyzed in this section will illustrate what kind of political controversies have been involved lately in discussing important industrial policy issues.

\section{A. Rationalization of the Finacnially Distressed or Structurally Depress- ed Industries}

The single most important but seemingly intractable problem in industrial policymaking in Korea has long been the problem of dealing with financially distressed firms(called Pulsilgiop)and the consequent huge amount of nonpcrforming debts accumulating in the banking system. Most of these firms 
started their business at the height of the heavy industrialization drive in the 1970s. To these group added new firms in the industries such as ocean shipping and foreign construction which had been selected and fostered by the government as "strategic industries" in the 1970 s but came to face severe structural depression in the early 1980s. The reason why the government has been intent on solving this problem is two-fold: first, the government itself is, in no small measure, to blame for the accumulation of non-performing debts; second, as a direct result of the first, there is a problem of "moral hazards" on the part of the commercial banks. As mentioned before, many attempts had thus been made to cope with this problem. The government's aborted attempts at restructuring of heavy industries between 1979-81 and the policymeasures designed to improve corporate financial structure in 1980 were the most significant examples.

The government's renewed initiative for industrial rationalization was undertaken in six episodes between May 1986 and February 1988, based on the revised "Tax Exemption and Reduction Law" and the new "Industry Development Law," both of which were, in essence, the debris of the EPB's "Industrial Assistance Law." In selecting firms to be subjected to industrial rationalization, the Industrial Policy Deliberation Council(IPDC) allegedly used the following somewhat ambiguous criteria: 1) structurally depressed industries necessitating industrial restructuring; 2) minor lines of conglomerate businesses (chaebol)needing streamlining; and 3) firms continuously accumulating non-performing debts particularly due to mismanagement. Among 78 firms, subjected to rationalization, 57 firms changed hands, 19 merged, and the remaining 2 were liquidated. Total financial assistance (in the form of rescheduling the payments of interest and principal and the new credit called "seed money") and tax benefits, provided in the rationalization process, amounted to 11,418 billion won(about $16.34 \$$ billion, estimated at 700 won per dollar) (Meil Kyungje Shinmun, July 21, 1988).

Most of the important decisions were made in entire secrecy, and, therefore, even the fundamental underlying motive of the massive rationalization initiative still remain obscure. Some information was for the first time revealed in the spring of 1989 through the National Assembly hearings, televised nation-wide, on the "anomalies of the Fifth Republic under Chun," suggesting somewhat strongly that some illegitimate political funds was collected in the process of selecting firms and providing huge financial and tax privileges to the merger firms. But more detailed information is definitely in need. At any rate, as long as the government's rationalization efforts proved, in effect, conducive to a further concentration of economic power in the hands of businessmen in particular allegiance to the Fifth Republic, the "politics-industry nexus(called chungkyungyuchak)scenario" seems to have more explanatory power. It was only natural that the public, the opposition parties and the so far alienated, minor groups of society, were outraged. And, more importantly, the rationale of industrial rationaliza- 
tion in the goverment's initiative has since become irreparably tainted and discredited.

\section{B. Restructuring of Daewoo Shipbuilding Co.}

The episode of restructuring Daewoo Shipbuilding Co.(location: Goche island; annual production capacity: 1.2 million $\mathrm{M} / \mathrm{T}$; and employees: 13.4 thousand) shows a new approach to problematic firms that the current government has come to rely upon in the aftermath of exposé of industrial rationalization attempts seen above. The building of the shipyard was originally undertaken by Korea Shipbuilding Corporation, a public enterprise, in 1973. But in 1978, when the construction faltered, then Park government decided to privatize it by handing it over Daewoo, which would have to invest additional money to own $51 \%$ of equity, while the Korea Development Bank(KDB) took the remainder. Since then, both Daewoo and $\mathrm{KDB}$ has put additional money to offset accumulating operating losses in the face of structural depression of the shipbuilding industry. In addition, during 1987-88, labor disputes and the consequent rapid wage increases complicated its normal operation, driving the firm further into debt, which stood at 1,100 billion won(about S1.57 billion) at the end of 1988 .

Again in the summer of 1988 , labor dispute struck the company. At the brink of bankruptcy, the owner of the company countered the labor union's request for wage increase by lockout. In the mood of political democratization, the Rho Tae Woo government first maintained its hands-off policy, leaving the issue to be settled through negotiations between the management and labor. As the adverse impact on the labor and the regional economy began to be felt, however, the opposition parties and the labor strongly demanded that the government intervene for its resolution, implying that the government should bail out the firm. In short, a totally different ball game was now played: The government wanted to keep the problem at arm's length, while the others wanted the government to intervene.

In these circumstances, the government began to take a different approach now. In October 1988, the MCI proposed that the government provide support only on the quid pro quo basis: that is, the government's support should be made conditional on the firm's demonstration of strong commitment to revive the firm and willingness to take every self-relief measure prior to goverment's assistance. In the meantime, the government was supposed to investigate the financial position more closely and reevaluate its prospects. Upon this proposal, pros and cons were submitted. On the pro side, a strong case was made that the industry demand has begun to pick up. On the opposition side, it was argued that the industry is nonetheless declining and an inefficiently-managed firm should be let die. In December, Kim Woo Chung, owner of Daewoo, testified before the Finance Committee of the National Assembly, that he would invest 300 billion 
won by selling out 5 other minor Daewoo companies ( 200 billion won) and other stocks(100 billion won), if the KDB invested the equivalent sum of money; and then he would diversify production lines(into light airplane and helicopter) and disclose the firm for public ownership in five years. In order to enable the bank to invest more into the firm, the National Assembly immediately passed the amendment of KDB Law to replenish its capital by 500 billion won, although the bank was reluctant to do so.

In January 1989, the MCI elaborated its proposal further. It suggested that the firm adopt a cutback management strategy: to reduce its labor force by $15 \%$ each year until 1993; and to double its productivity in five years. And this proposal was concluded in March 1989 as the final government policy. Along this line of policy, the government rescheduled the Daewoo's debt with the KDB, designated it as an "industrial rationalization firm" to grant tax privileges, and promised that the $\mathrm{KDB}$ would provide additional loan, which would be contingent on Daewoo's undertaking of self-relief efforts by June 1990. Whether or not the Korean government's "new deal,"(Reich and Donahue 1985: pp. 160-205), instead of unconditional bail-out, will really work remains to be seen.

\section{Decision to Privatize Korea Heavy Industries Co.}

Among the government's drastic heavy industrial restructuring attempts during 1979-80, the most problematic sector was power generating equipment in which Korea's three largest chaebol groups participated. Hyundai Yanghaeng (note that it was not part of Hyundai.), which launched the biggest project in 1976, was in deep financial trouble. By the end of 1978 , it had invested over $\$ 200$ million in a huge integrated machinery plant, but needed another two hundred million to complete the project. Its capital-asset ratio was meager 8 percent at the end of 1978 , far short of the target level $(30 \%$ in $1979,35 \%$ in 1981 , and $40 \%$ thereafter $)$ agreed between the Korean government and the World Bank, which lent part of an $\$ 80$ million loan. It was not feasible either for Hyundai Yanghaeng or the government to put additional money into the project (KDI 1981: pp. 1149-1173). Moreover, the goverment could not simply let Hyundai Yanghaeng monopolize domestic supply of power generating equipment, since by 1979, Hyundai, Samsung and Daewoo had already put some money in this sector and claimed their fair shares of the domestic supply contracts. This situation would represent another breach of the promises made to the World Bank.

The first restructuring attempt was made in 1979. The government intended to merge four such investment projects into two: Hyundai Heavy industries and Hyundai Yanghang as one group, and Daewoo and Samsung Heavy Industries as the other. But the government's proposal was not accepted by the rival business groups, although the former group had made some progress toward a merger. The Hyundai Group pleaded for various kinds of government support and pri- 
vileges, almost all of which the government grudgingly granted. Nonetheless the merger attempt was unsuccessful. As the problem loomed larger, an even bolder restructuring attempt was made in August 1980(Ibid.: pp. 1199-1214). The government decided to unite Hyundai Yanghaeng and Daewoo into Korea Heavy Industries Co.(KHIC) to be managed by Daewoo, and guarantee the company monopoly right to the supply of power generating equipment and heavy construction equipment. But, the capital requirement and related government assistance necessary to rescue the ailing company was so huge that the idea of creating a public corporation reemerged and prevailed this time. In October 1980 the KHIC was turned into a public enterprise in which the Korea Development Bank, Korea Foreign Exchange Bank, and the Kurea Electric Power Corporation(KEPCO) invested, while the $\mathrm{KEPCO}$, as its major customer, exercised managerial control. In June 1982, the construction of KHIC's huge integrated machinery plant was completed.

But the KHIC, as a fledgling, inexperienced company in the industry marked by an intense technological and marketing competition, has not only failed to secure market(due mainly to the delay of the national electricity development plan), but displayed many managerial inefficiencies as a public enterprise. Too rigid budgetary procedures obstructed its swift decision-making and aggressive sales activities. In addition, prominent technicians and employees left the company. As a result, it has been recording operating losses.

Under these circumstances, in February 1988, just before President Chun left his office, the MCI Minister Ahn Byung Hwa, formerly KHIC president, reported to President Chun a plan to privatize it, and the President consented. But since the inauguration of President Rho, the issue has been left in the dark. In April 1989, under the leadership of the newly appointed Deputy Prime Minister, Chough Soon, the policy of privatizing KHIC has been subjected to critical review. The EPB has been worried about that privatization would exacerbate economic concentration, since whichever chaebol would come to own it, it would be possible only with the provision of huge bank loan. Furthermore, it believed that, once KHIC is privatized and the private firm asks for government help, in whatever form it may be, it would be very difficult for the government to deny it. Given this highly plausible situation, the EPB thought that there is no point in privatizing the problematic firm. Moreover, as the national electricity development plan is envisaged to come into force from 1992, and as it would certainly make KHIC operation profitable, the timing of privatization should be reconsidered for the benefit of the whole nation.

But the MCI, the Ministry of Energy and Resources, the KEPCO, and investor banks all pressed for privatization in view of the KHIC's manifest managerial inefficiencies. Even the KHIC's labor union was in favor of privatization. In August, the Blue House intervened and upheld the privatization course. It is still 
unclear why the Blue House and President Rho has decided to go in for privatization. Some suspect that Hyundai(which has some stake to claim in the matter), Samsung, and other chaebol groups had exerted political influence at the final stage of the decision-making. The National Assembly has generally shown much sympathy toward the EPB's cause. The opposition parties were opposed to the plan. In any way, reflecting the EPB's concern and the National Assembly, the terms and conditions of privatizing KHIC have been made unusually strict: Any firm which wants to own it has to pay for it without recourse to privileged bank loan(meaning that it has to sell its land holdings or stocks); Monopoly right to domestic construction contracts will not be granted to the prospective buyer. Given its strict conditions, it is not certain whether the privatization will materialize at all. If it fails, the KHIC will keep its current name and status for some years to come.

Whatever result would obtain, this episode nonetheless represents another case of departure from the conventional industrial policymaking in Korea. Particularly in the aftermath of scandalous massive industrial rationalization during 1986-88, the Korean government has stopped the habit of coming directly to rescue troubled firms; instead, it weighs political considerations even when the cause seems to be warranted. And it tends to look for a wider array of industrial policy instruments with greater reliance on market forces and private sector autonomy. Most importantly, the government seems to learn to respect private businessmen's superior managerial judgment.

\section{Conclusion}

In any country, the conception of industrial policymaking reflects its peculiar political, economic, and social context. The change in the conception of industrial policymaking in Korea is not an exception. For example, as we have examined by way of analyzing the recent industrial policy episodes, many important changes in industrial policymaking have taken place since the inception of the current government. But what is unique in the case of Korea has been a coherent industrial policy reform undertaken during the transitional period from the Yushin regime to that of Chun, while both regimes were authoritarian. The underlying motive was to correct policy failures and legacies left by the highly politicized heavy industrialization drive in the 1970s. In addition, although it has been deliberately downplayed in this paper to put greater emphasis on the inefficiencies and ill effects of traditional industrial policy on the domestic scene, the everincreasing foreign governments' pressure to eliminate unfair trade practices have since the mid 1980s played an important part in bringing about the change in Korean industrial policy.

It may be too early to say definitely that the new conception of industrial policymaking in Korea has taken root firmly. If the economic condition changes 
adversely, this trend may be reversed. But given the analysis above, it would be fair to say that Korean industrial policy has come to bear a closer semblance to that of advanced industrialized countries, as the country is well on the course of political and economic democratization(Choi 1988). The concept of industrial targeting, which has long dominated the industrial policymaking in Korea, seems to have lost its traditional luster. The government policymakers tend increasingly to shy away from it. And they abhor the possibility of being hamstrung when they intervene too deeply into private investment decisions.

On the other hand, the opposition political parties, so-far alienated societal groups and the like demand that the government intervene to foster so-far neglected sectors of economy. For instance, they insist that the government's role in fostering medium and small-sized enterprises and in dealing with declining industries. But as sufficient experiences in the developed countries have already demonstrated, this is the industrial policy area where its economic justification is in short supply. In short, in the future, Korea's industrial policy failures, if any, may be more likely to appear in dealing with declining industries rather than growth industries, as political influence has begun to overshadow technocratic judgments in the making of industrial policy.

\section{References}

Aggarwal, Vinod with Haggard, Stephen. "The Politics of Protection in the U.S. Textile and Apparel Industries," in John Zysman and Laura Tyson(eds.), American Industry in International Competition (Ithaca: Cornell University Press, 1983)

Aghevli Bijan B. and Marquez-Ruarte, Jorge. A Case of Successful Adjustment: Korea's Experience During 1980-84, Occasional Paper No. 39, International Monetary Fund, August 1985. Bank of Korea. "Foreign Loans by Industry, 1962-82," 1983. Financial System in Korea, September 1985.

Barzelay, Michael. The Politicized Market Economy: Alcohol in Brazil's Energy Strategy (Berkely: University of California Press, 1986).

Cho, Yoon Je and Cole, David C. "The Role of the Financial Sector in Korea's Structural Adjustment," Development Discussion Paper No. 230, Harvard Institute for International Development, May 1985.

Choi, Byung-Sun. "Institutionalizing a Liberal Economic Order in Korea: The Strategic Management of Economic Change," Unpublished Ph.D Dissertation, Harvard University, June 1987.

"Political and Economic Democratization and Its Impact on the Government-Business Relationship in Korea," in The Korean Journal of Policy Studies, Vol. 3(1988).

Economic Planning Board(EPB). " 80 Nyondae Sanopjongch" aekui Kwajewa Chiwonshich' aekui Kaepyonbanghyang,"(Industrial Policy Issues in the 1980s and the Direction for Rearranging Industrial Assistance Measures), May 27, 1983.

Kaebalnyondaeui Kyongjejongch'aek: Kyongjegihoekwon Isip- 
nyonsa (Economic Policy in the Development Decades: The Twenty-Year History of the Economic Planning Boards Seoul, 1982).

- "Urikyongjeui Hyonshilgwa Kwaje(The Reality and

Tasks of Our Economy), February 1984.

Major Statistics of Korean Economy, 1980.

Federation of Korean Industries(FKI). "Suip Chayuhwadaech'aeke Kwanhan Chonghapkonui," (Comprehensive Policy Recommendations about Import Liberalization Countermeasures), December 1983.

Fishlow, Albert, Carriere, Jean, and Sekiguchi, Sueo. Trade in Manufactured Products with Developing Countries: Reinforcing North-South Partnership,A Report to the Trilateral Commission(New York: Trilateral Commission, 1981).

Frank, Charles R. Jr., Kim, Kwang Suk, and Westphal, Larry. Foreign Trade Regimes and Economic Development: South Korea(New york: National Bureau of Economic Research, 1975), A Special Conference Series on Foreign Trade Regimes and Economic Development, Vol. VII.

Haggard, Stephen and Moon, Chung In. "Industrial Change and State Power: The Politics of Stabilization in Korea," presented for the Annual Meeting of the American Political Science Association, Washington, D.C., August 27-31, 1986.

Hirschman, Albert O. "The Political Economy of Import-Substituting Industrialization in Latin Amcrica," in A Bias for Hope: Essays on Development and Latin American (New Haven: Yale University Press, 1971).

Johnson, Chalmers. "Political Institutions and Economic Performance: The GovernmentBusiness Relationship in Japan, South Korea, and Taiwan," in Scalapino, Robert A., Sato, Seisaburo, and Wanandi, Jusuf(eds.). Asian Economic Development-Present and Future (Berkeley: University of California Press, 1985), Institute of East Asian Studies, University of California, Berkeley, Research Papers and Policy Studies No. 14.

Jones, Leroy P. "Jac-Bul and the Concentration of Economic Power in Korean Development: Evidence and Alternatives," Korea Development Institute Consultant Paper Series No. 12. July 1980.

Kim, Kwang Suk and Hong, Seong Duk. "Myongmokmit Shilhyobohoyulgujoui Changgijokbyonhwa(Long-Term Changes in Structure of Nominal and Effective Rate of Protection)," Korea Development Institute Research Report 82-02, 1982.

Korea Development Bank(KDB). 80 Nyondaeui Cholyaksanop (Strategic Industries in the 1980s; Seoul, 1981).

Korea Development Institute(KDI). "Suip Chayuhwa Daejongbukonui: Yoyak"(Policy Recommendation to the Government on Import Liberalization: Summary), KDI Issue Paper(unpublished), March 10, 1983.

. Kyongjae Anjonghwa Sich' aek Charyojip(Sang \& $\mathrm{Ha}$ ) (Collected Documents of Economic Stabilization Measures; Seoul, 1981).

Korea Insutitute of Industrial Economics and Techology(KIET). "1980 Nyondaeui Sanopchogch'ack Banghyang (Direction of Industrial Policy in the 1980s)," August 18, 1982 and November 1982.

Krugman, Paul R. "Trageted Industrial Policies: Theory and Evidence," Discussion Paper, MIT, 1983.

Lim, Youngil. Government Policy and Private Enterprise: Korean Experience in Industrialization 
(Berkeley: University of California Press, 1981), Korea Research Monograph, Institute of East Asian Studies, University of California, Berkeley, Center for Korean Studies. Mason, Edward S., Kim, Mahn Je, Perkins, Dwight H., Kim, Kwang Suk, and Cole, David C. The Economic and Social Modernization of the Republic of Korea(Cambridge, Mass: Harvard University Press, 1980), Studies in the Modernization of the Republic of Korea: 1945-75, Council on East Asian Studies, Harvard University.

Ministry of Commerce and Industry $(\mathrm{MCl})$. "Heavy and Chemical Industry Development Plan." May 1973.

Nam, Sang-woo. "Korea's Stabilization Efforts Since the Late 1970s," Korea Development Institute Working Paper 8405, March 1984.

OECD. The Impact of the Newly Industrialising Countries on Production and Trade in Manufactures, Report by the Secretary-General (Paris: OECD, 1979).

Park, Yung Chul. "Economic Stabilization and Liberalization in Korea 1980-84," in Monetary Policy in a Changing Financial Environment(Seoul: Bank of Korea, 1985), Proceedings of the Seminar Commemorating the 35th Anniversary of the Bank of Korea, held on June 12, 1985.

Park, Yung Chul, “70 Nyondaeui Koemul 'Chunghwahak Yamang,'(Monster in the 1970s 'The Ambition of Heavy and Chemical Industrialization,' in Chongkyongmunhwa, May 1984.

Reich, Rober B. and Donahue John D. New Deals: The Chrysler Revival and the American System(New York: Times Books, 1985).

Roberts, Gerald. South Korea to 1990: Liberalization for Growth, Special Report No. 225, The Economist Intelligence Unit, 1985.

Schultze, Charles L. "Industrial Policy: A Dissent," in The Brookings Review (Fall 1983). Woolcock, Stephen. "Textiles and Clothing," in Turner. Louis and McMullen, Neil (eds.). The Newly Industrializing Countries: Trade and Adjustment(Hemel Hempstead: George Allen \& Unwin, 1982).

Young, Soogil. "Import Liberalization and Industrial Adjustment in Korea," Working Paper 8613, Korea Development Institute, December 1986. 